\title{
THE MAIN EVOLUTION REFERENCES OF COPYRIGHT IN ANTIQUITY AND THE MODERN ERA
}

\author{
Tudor-Vlad SFÂRLOG \\ "Lucian Blaga” University, Sibiu, Romania \\ tsfarlog@yahoo.ro
}

\begin{abstract}
The present study integrates into the complex scientific approach of investigating the legal protection of the rights that result from the intellectual creation in the Romanian objective law. In this regard, it analyzes the main evolutionary benchmarks of the protection of intellectual creation from ancient times to the modern era, aiming to highlight the elements of social nature that were the basis of the emergence and development of copyright. At the same time, the scientific approach addresses the issue of the emergence of copyright by combining, through the method of multi-disciplinary scientific research, the legal, social and historical sciences. In the accomplishment of the present scientific approach we used the following scientific research methods: the historical method, the logical method, the deductive-inductive method and the comparative method.
\end{abstract}

KEYWORDS: copyright, intellectual property, intellectual creation, publishing

\section{Introduction}

Today it is commonly accepted that between socio-economic development and the protection of intellectual rights there is an indissoluble connection. Obviously, the progress of society is closely linked to the creations of individuals. Thus, the protection of the legitimate interests of authors and inventors protects both the individual interests and the social need for continuous improvement and adaptation.

The evolution of the society, closely related to the spiritual activity of the individual, to their ability to capitalize and develop the informational accumulations of their predecessors, to discover, invent and create, has generated and generates the need for copyright regulation. Thus, the issue of intellectual property in general, and in particular that of copyright, is known in its historical evolution, starting with the period of antiquity during which we could only speak of a recognition of moral rights, permanent and profound reconsiderations and revisions up to the complicated and constantly changing laws of the information society era.

If today the rights of intellectual creation are unanimously considered as sui generis rights, trying to respond as closely as possible to the continuous progress, globalization and technological upgrading, the first copyright law is considered to have been adopted in England, in the first part of the eighteenth century. This is what Statute of Anne (1709) stated, assigning an exclusive copy right to the authors. The first copyright regulation had an initial duration of 21 years, and it was later extended. 
The dynamics of social relations in the field of copyright determines the analysis and reconsideration of objective law in the field of copyright. The dynamics of social relations in the sphere of copyright is mainly characterized by the need to adapt in the context of globalization, technical, technological, industrial progress, etc. from the last decades that have generated, among others, a significantly larger number of categories of goods in the civil circuit that "enjoy" the protection of intellectual rights. This fact led to the development and adaptation of international and domestic laws in the field of intellectual property to correspond to the new state of affairs.

The possible delay of the legal regulations must be assessed in the light of a complex, multidisciplinary analysis.

\section{About Intellectual Creation}

$A b$ initio, a scientific approach by which the authors intend to identify and analyze the evolutionary landmarks must in all cases include the analysis of terminology issues, especially cases where the doctrine is not unitary. Thus, we will agree with the opinion that the expression of intellectual creation right is more suitable for use in legal texts concerning the overall legal protection of this product of the human intellect. The same idea is found in the specialized doctrine, according to Bodoașcă T. (2010; 2012).

Therefore, by the present scientific approach, we intend to carry out an evolutionary analysis of the copyright, from the ancient times to the main European regulations of the $19^{\text {th }}$ century, taking into account also the Law of the Press from April 13, 1862. The research activity will include the evolution of the copyright in the main European and United States law systems correlated with the regulations of the Romanian National Law, trying to establish the elements of harmonization between the objective law and the comparative law.

\section{Legal Protection of Intellectual Creation in Antiquity}

In the ancient times we will analyze whether and to what extent the authors benefited from the protection of their works. Thus, in ancient Rome there were contracts between the author and the librarian, especially regarding the multiplication of literary works. However, these conventions are devoid of "legal protection", which does not give the act the necessary force to compel the contractor to execute its obligations in the absence of regulations regarding the right to multiply literary works. Even more, it is claimed that sometimes the authors were slaves, but the owners of the intellectual creations of the slaves were their owners, under a right of accession (Roş, Bogdan \& Spineanu-Matei, 2005).

Not only that both in Rome and ancient Greece, the authors were not protected against the phenomenon of "plagiarism", the concept of plagiarism itself did not have the meaning of today. Although there are historical sources that prove the condemnation of some plagiarists, the meaning of the term is closer to theft in the material sense, and not to the appropriation of a product of the spirit whose main quality is originality. In this sense, in ancient Rome, plagiarists were considered persons who stole children and then sold them as slaves.

The term "plagiarism" has undergone a process of transformation, gaining the meaning used nowadays since the sixteenth century. In this context, analyzing the meaning of the term, it would be difficult to consider that between the theft of children to unfairly exploit them in antiquity and the fraudulent acquisition of ideas or fatherhood of works nowadays there is a continuity connection, even if both elements presuppose, on the one hand, a premised creative activity and, on the other, a fraudulent assumption of it by a person in order to use it. Although the individual's life was not as well protected as it is in 
contemporary times, there are major differences in terms of harmed social value between the two meanings of the term, for which we are entitled to state that the main meaning of the term "plagiarism" has undergone a process of transformation over the centuries.

In the absence of legal regulation of copyrights during antiquity, both in Rome and Greece, plagiarism, in its contemporary meaning, was subject to public blame, and those who wrongfully assumed works were considered unworthy, plagiarism being considered a dishonorable action (Roş, Bogdan \& Spineanu-Matei, 2015).

Undoubtedly, both Rome and Athens experienced a high degree of development in the ancient period. Referring to the idea in the first paragraph, according to which there is a connection between the development of the society and the protection of intellectual property rights, the progress achieved in the ancient period by the two civilizations could be questioned. However, the lack of means of reproduction of literary and artistic works, in conjunction with the public objection to which plagiarists were subjected, justifies us to affirm that there is a certain concern within the cities for the protection of intellectual creation rights. Thus, considering the arguments, we consider that in the absence of the means of multiplying the manuscripts, the lack of legal protection of the copyright is a natural consequence, and the public objection expressed against the plagiarists tends to ensure sufficient protection of the moral rights of the authors, especially considering the social peculiarities of antiquity. In support of this belief are the statements of the historians Phillippe Aries and Georges Duby who outline life in the ancient city of Rome as a place where, "the fear of public opinion plays an important role in private life, and the public considers itself entitled to judge it [...] it is assumed that a novel does not have a private life; any novel can be addressed to the public" (1994, p. 56). Moreover, the civil trial was mostly a wish in ancient Rome, despite the greatness of Roman civil law. Thus, an eloquent illustration is represented by the model offered by G. Duby in the text with a marginal name "Did there exist the Roman law?". In this regard, the two authors question the efficiency of the norms of the Roman law. We rightly believe that in the absence of procedural rules that effectively regulate the way in which material law is valorized and protected, its very existence can become questionable.

Similarly, in ancient Greece, copyright protection was the same. Even though the Greeks differ from the Romans, who considered wealth a virtue, thinking that pecuniary remuneration was the measure of success, the Greeks were mainly seeking public recognition, attributing secondary interest to pecuniary success. However, public contempt reached a more critical level in ancient Greece. Proof of this is the multiple historical sources offered for example in the specialized doctrine.

If, in ancient times, the application of the laws was strongly influenced by the personal circumstances of the subjects of law, the question arises whether certain regulations would have been useful or not. Certainly, the degree of copyright protection would have been met to a greater extent also by the citizens of the cities.

The Middle Ages did not, besides the development of the trade in manuscripts, bring major changes in intellectual property rights. On the contrary, copyright takes shape in the Renaissance Age with the invention of the print by Johannes Gutenberg. Following Gutenberg's invention, the print spreads rapidly throughout Central and Western Europe. We appreciate that, as the print would have developed faster in Europe (historical sources say that the print appeared in the second century AD in China), the legal regulation of copyright would have seen an 
early development. In view of the long period of time when the instruments of printing and multiplication of the manuscripts have not seen significant improvements, the creative activity of the human spirit has not benefited from the social and legal support favorable to the development. In this sense, the appearance of the print offered the technical support necessary for the development of the creative side of the society. Thus, exceptionally, we can state that an instrument, the print, was the basis of the birth of an institution, respectively of copyright. As Eminescu Y. (1987) points out, in the his work, the factors that determine the irregularity of the situation mainly focus on the deficiencies of the society caused by the lack of symbiosis between the regulation of copyright and the main socio-economic aspects. As a result of the development of the print, the new books multiplied, the author's work, the bookstore industry became more profitable (...) Everyone who (...) makes a legitimate profit from the intellectual activity feels the need to resort to social protection.

According to T. Nótári (2011), the first legal sources of copyright are acts by which the rulers individually grant privileges to certain publishers or, as the case may be, to the author, thus monopolizing the printing and publishing of books. However, we note that these acts are deficient in at least two points of view. First, the rules that contain them do not establish general rules applicable to all legal subjects, instead regulating particular situations, of strict interpretation. Secondly, even if the situation actually dates to the latter part of the sixteenth century, we note that in the event that the author could have had his work in terms of editing and multiplication, then this would have been considered a privilege, a fact deeply contested by German philosophers at the end of the seventeenth century. Thus, in 1709, Queen Anne Stuart issued a law ending the monopoly of the booksellers' guild (Stationers Company). The royal decree granted the author or the person designated by it exclusive rights on the copies of a work for a period of 28 years. After the expiration of the 28-year period, the author loses the copyright. The same legal regulation was also adopted by the United States of America in 1790, but it was modified in 1831.

In Prussia, the legislator did not initially create the copyright, but attributed the right to multiply the print only after signing a written agreement with the author. However, in 1837 the legislator adopted a law on the protection of property resulting from scientific and artistic works. The law granted intellectual property protection for 30 years after the author's death.

In 1865 the Bavarian law on copyright was adopted, and in 1870 the law on copyright was adopted on writings, drawings, musical compositions and dramatic works, considered to be the first law of the Empire. Under both laws, every German citizen enjoyed the protection of their works, no matter where they were published, provided that the publication was done through a publisher based in Germany.

The evolution of regulations in the field of intellectual property rights in France has been slower.

However, the most important rules for the protection of intellectual creation have been outlined in France. In addition to the legislative framework, jurisprudence has played a significant role. In this regard, the pleadings of lawyers Louis d'Hericourt and Cochu were illuminating, according to whom, "if there is a sacred, obvious, undeniable property, that is the authors'. '”(Bertrand, 1995, p. 117). Following Cochu lawyer's pleadings, a new law on the right of reproduction was adopted in 1793, which came to correct the decisions of the French Royal Council of 1777. The law reiterated, to a large extent, the pleadings of lawyers d'Hericourt and Cochu. Bertrand A. (1995) also states the same. 
In Romania, the concerns regarding the law of intellectual creation were almost non-existent until the $19^{\text {th }}$ century. With regard to copyright, Romania adopted, on April 13, 1862, the Law of the Press, which regulated the rights of authors of literary and artistic works. The law had as model the French law of 1793. Like the French law, the Law of the Press proclaims the right of authors to enjoy the right to reproduce, assign and sell their works, just as a property. However, a number of new situations have been mentioned in the Law of the Press. Of these, the most important was the principle of reciprocity, by virtue of which foreign authors could obtain the recognition of copyright in Romania. The law, considered to be a modern one in Romania, created at that time a series of non-unitary jurisprudential judgments. Eloquent are the judgments of the Tribunal in Ilfov of March 17, 1882 and of May 19, 1882 and are dealt with exhaustively in the specialized doctrine (Romițan, 2011).

Although the national regulations provided the intellectual creation rights with the necessary legal protection and served as a catalyst for the emergence of new creations, they had in the first phase an essentially national character. Since the legal regulations referred only to the territory of the issuing country, they did not provide protection to foreign authors. The protection of foreign authors, so practically, the legitimate circulation of intellectual creation, became in the last part of the nineteenth century, a process that had to be urgent at any cost. The creative spirit of the geniuses of the time could not be restrained within the territorial limits which at that time were hindering progress. For these reasons, the Paris Conventions of 1883 for the protection of industrial property, respectively the Conventions in Bern of 1886 for the protection of literary and artistic works, appeared successively in the latter part of the century.

\section{Conclusions}

In conclusion, the following main ideas and elements of originality can be outlined following the present scientific approach. First, in antiquity, despite the lack of legal protection of intellectual creation rights, we argued that a certain degree of concern existed for this category of rights within cities, both civilizations, both Roman and Greek, putting knowledge upon the pedestal of progress. Secondly, we have highlighted the process of transforming the meaning of the term "plagiarism", excluding a possible misinterpretation of the term in the archaic meaning. Thirdly, we formulated and argued the point that the appearance of the pattern was the basis of the birth of the copyright. Fourthly, we highlighted the main evolutionary benchmarks of intellectual property rights: the emergence of printing in Europe and the first legislative regulations in the field. Fifthly, we highlighted the correlations between the European legislation and the Romanian legislation in the field, as well as the novelty elements brought by the Romanian legislator.

\section{REFERENCES}

Aries, P., \& Duby, G. (1994). Istoria vieții private. Vol. I, București: Editura Mediterane.

Bertrand, A. (1995). La propriété intellectuelle, Livre II, marques et brevets, dessins et modèles. Paris: Delmas,_Belfond.

Bodoașcă, T. (2012). Consideraţii asupra drepturilor rezultate din creaţia intelectuală în reglementarea noului Cod civil (Legea nr. 287/2009). Revista Dreptul, nr. 6. 
Bodoașcă, T. (2012). Dreptul proprietății intelectuale. Ediţia 2 revăzută, București: Editura Universul Juridic.

Eminescu, Y. (1987). Opera de creație și dreptul: O privire comparativă. București: Editura Academiei Republicii Socialiste România.

Nótári, T. (2011). Evoluția dreptului de autor maghiar în perspectiva internațională. Revista Acta Sapientia, $n r .3$.

Romițan, C. R. (2011). 149 ani de la adoptarea în România a primei legi care a reglementat drepturile autorilor de opere literare și artistice (1862-2011). Revista română de dreptul proprietăţii intelectuale, $n r .1$.

Roș, V., Bogdan, D., \& Spineanu-Matei, O. (2005). Dreptul de autor și drepturile conexe. Tratat. București: Editura All Beck.

Stuart Anne, Queen of Great Britain. (1709). An Act for the Encouragement of Learning, by vesting the Copies of Printed Books in the Authors or purchasers of such Copies, during the Times therein mentioned (Stationers Company). Parliament of Great Britain. 